\title{
Headache, alcoholic consumption, and medical student
}

\author{
Cefaleia, consumo de álcool e estudantes de medicina
}

Beuy Joob ${ }^{1}$ Viroj Wiwanitkit ${ }^{2}$

\section{Dear editors,}

The recent publication on headache, alcoholic consumption, and medical student is very interesting ${ }^{1}$. Domingues and Domingues concluded that "having headache leads to a reduction in alcohol consumption among medical students regardless the degree of headache functional impact ${ }^{1}$. All data in this paper were derived by the questionnaire, hence the problem of bias cannot be excluded. In addition, there is no subjective evidence to exclude or find the pathology in subjects with headache. In cases on alcoholic drinking, it is also interesting to realize if the exact kind of beverage is known. Different beverages contain different levels of alcohol and this can result in different levels of headache and drowsiness. Finally, although it is not directly related to the neurological aspect it is surprisingly that medical students drink alcohol. Indeed, medical personnel should be the role models for good health behavior practice.

\section{References}

1. Domingues RB, Domingues SA. Headache is associated with lower alcohol consumption among medical students. Arq Neuropsiquiatr 2011;69:620-623.

\section{Reply}

\section{Reposta}

Renan Barros Domingues, Simone Aires C. Domingues

Dear editors,

Doctors Beuy Joob and Viroj Wiwanitkit present some interesting comments about our paper. First, they say that "data in this work were derived by the questionnaire, hence the problem of bias cannot be excluded". We agree and we recognize this limitation in the discussion when we say: "Our study has some clear limitations. The IDmigraine is a screening tool. Although it has been validated in Portuguese language it has not the same accuracy than a clinical evaluation by a headache expert using the International Headache Criteria. The evaluation of the alcohol intake was based on retrospective information and did not discriminate the type of alcohol beverage; however, AUDIT is a largely validated tool" .

Second, the authors suggest that different beverages contain different levels of alcohol and this can result in different levels of headache. We also agree. This study was only to evaluate the impact of alcohol with AUDIT and its correlation with headache. We are currently evaluating the effect

\footnotetext{
1 Sanitation 1 Medical Academic Center, Bangkok;

${ }^{2}$ Wiwanitkit House, Bangkhae, Bangkok Thailand 10160.

Correspondence: Beuy Joob; Sanitation 1 Medical Academic Center, Bangkok; E-mail: beuyjoob@hotmail.com Conflict of interest: There is no conflict of interest to declare.

Received 20 September 2011; Accepted 29 September 2011.
} 
of different types of beverages in another study. We appreciate the valuable suggestion.

Third, our colleagues state that "it is surprisingly that the medical students drink alcohol. Indeed, medical personnel should be the role models for good health behavior practice”. Unfortunately, alcohol consumption and alcoholrelated problems among medical students have been reported in several countries. The references are listed on such subject $^{2-9}$. We intended only to address a particular aspect (headache) of this recognized public health problem.

\section{References}

1. Domingues RB, Domingues SA. Headache is associated with lower alcohol consumption among medical students. Arq Neuropsiquiatr 2011;69:620-623

2. Deressa W, Azazh A. Substance use and its predictors among undergraduate medical students of Addis Ababa University in Ethiopia. BMC Public Health 2011;11:660.

3. Nola IA, Jelinić JD, Matanić D, Pucarin-Cvetković J, Bergman Marković B, Senta A. Differences in eating and lifestyle habits between first- and sixthyear medical students from Zagreb. Coll Antropol 2010;34:1289-1294.

4. Kozhevnikova NG, Kataeva VA. Hygienic aspects of the lifestyle of medical students under the present conditions. Gig Sanit 2011:3:74-77.

5. Puig-Nolasco A, Cortaza-Ramirez L, Pillon SC. Alcohol use among
Mexican medical students. Rev Lat Am Enfermagem 2011;19:714-721.

6. Rustagi N, Taneja D, Mishra P, Ingle G. Cardiovascular risk behavior among students of a medical college in Delhi. Indian $\mathrm{J}$ Community Med 2011;36:51-53.

7. Pham DB, Clough AR, Nguyen HV, Kim GB, Buettner PG. Alcohol consumption and alcohol-related problems among Vietnamese medical students. Drug Alcohol Rev 2010;29:219-226.

8. Htay SS, Oo M, Yoshida Y, Harun-Or-Rashid M, Sakamoto J. Risk behaviors and associated factors among medical students and community youths in Myanmar. Nagoya J Med Sci 2010;72:71-81.

9. Horwitz ZB. Smoking and alcohol drinking among medical students. Rev Med Chil 2009;137:1400; author reply 1401. 